\title{
A METHODOLOGY FOR ILLEGAL SETTLEMENTS RE-CONVERSION
}

\author{
D. CIALDEA \& N. QUERCIO \\ L.a.co.s.t.a. Laboratory University of Molise, Campobasso, Italy.
}

\begin{abstract}
This paper describes the phenomenon of illegal settlements. The case study focuses on the Molise region in the South of Italy, which is characterized by the absence of wide-area plans. In fact, the weakness of the existing plans at municipal level meant that the increase in buildings could not be controlled, especially in non-urban areas. This resulted in urban areas, planned for the supply of services, remaining agricultural zones and agricultural areas becoming useful for new residential expansions. Our dissertation explores the effects of Molise Regional Law no. 17/1985, following the enactment of National Law no. 47/1985 (rules for building planning control). The national law imposed on municipalities the task of cordoning off illegal settlement areas in order to reclassify them into new planning tools. The problem was that the new classification, oriented to residential utilization, requires the realization of appropriate facilities (urbanization, public parks, schools, parking areas, etc.) that do not actually exist. Consequently, in many cases it was necessary to draft appropriate renewal plans to include these facilities. In fact, the national law was oriented to support a special type of planning tool, delegating detailed rules to regions. This issue was analyzed by the l.a.co.s.t.a. Laboratory working group, officially placed in charge by the Molise Region, in order to set up the New Regional Landscape Plan, under the new National Code for Cultural and Landscape Heritage of 2004, as amended and supplemented.

Keywords: Agricultural Land, Illegal settlements, Landscape Quality
\end{abstract}

\section{INTRODUCTION}

In this paper, we analyze the context of great changes in the Central Molise Region where the regional capital is located, which inevitably must be analyzed with the ten small villages which surround it [1].

Our paper aims to highlight actual conflicts between agricultural uses and landscape issues. The lack of a Regional Planning Law generated really disparate tools, especially for these agricultural areas [2-5], in which there are a lot of 'settlement islands' within agricultural zones.

\section{PHYSICAL FORMS OF THE SETTLEMENT SYSTEM}

The case study concerns illegal settlements in the city of Campobasso and its hinterland, delimited in accordance with Article 5 of R.L. 17/85 [6]. Above all, these areas require rationalization and infrastructure integration. Moreover, the settlement system of the regional capital is closely related to migratory dynamics: especially over the last 30 years, there has been a population increase in some of the abovementioned villages around the capital, and a strong depopulation in others.

Building development in this area is the result of plans made only at the municipal level, which have been upgraded several times by general or partial modifications alone, without changing their original aims.

The first master plan of the city of Campobasso dates back to 1954, in place of the enlargement of the previous 1928 Plan. In 1966, following the establishment of the Molise Region, a general variation to the old plan was realized. This modification, still in force, was approved in 1972. The last attempt to update the Plan of Campobasso dates back to 2000: it was 
adopted by Resolution of the Municipality Council No. 82/2000 but was never approved by the region.

In this scenario, the analysis of demographic data from the last census showed that, while the population of Campobasso was almost unchanged, a significant population growth had occurred in municipalities located in its south-east area.

The fact that the Campobasso Plan was so old allowed building extension areas to be saturated in the late 1970s. On the other hand, however, the expansion of its neighbouring municipalities spread along the main connections to the capital [7-9].

Only 15 years after the legislative imposition to cordon off illegal settlements, architect Lucarino, Commissioner ad Acta, approved the modification of the old master plan. His report shows an overview of the area: the urban settlement of Campobasso was divided into three radial bands developed from the historical centre. The first band corresponds to the expansion of the XIX and XX centuries, strongly linked to the old settlement. The second band is characterized by multilevel buildings, named 'Palazzine', devoid of typological link with the previous zones. The third band identifies illegal areas, the so-called "perimeters", where, however, it is still possible to redesign the identity of sub urban settlement systems [10]. Therefore, these areas, falling into the agricultural zones, could become new open suburbs with services and infrastructures, well-connected with the old centre of the city (Fig. 1).

\section{REGIONAL ANALYSIS METHODOLOGY}

The methodology used in this paper starts from a survey on the current state of the urbanized areas affected by illegal building. Territorial analyses were carried out from regional data sources increased by the collection of in situ data.

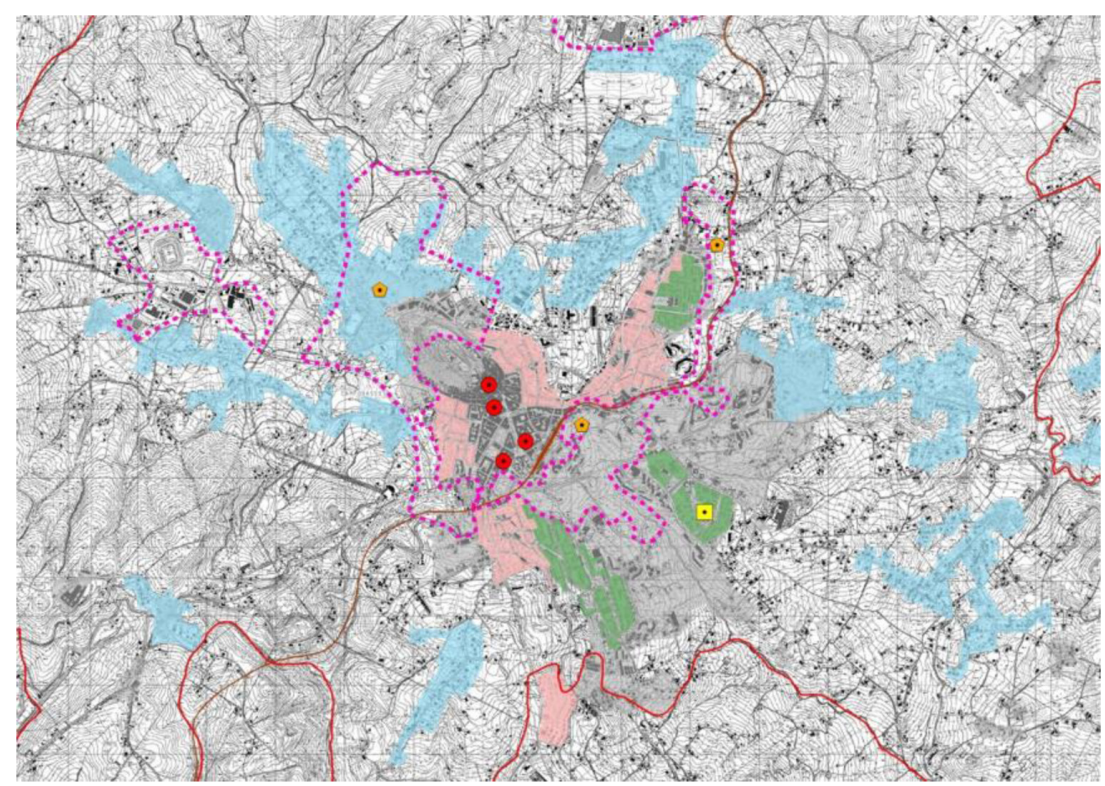

Figure 1: Analysis of illegal settlements in the Campobasso area (Source: Molise Region 1992 updated, Municipality of Campobasso 1972, 1.a.co.s.t.a. Laboratory Processing 2015). 
Several factors were analyzed: physical features of the landscape, infrastructure standards, preservation capacity and quality of the settlements. Therefore, the work was divided into the following phases:

1. Diachronic analysis in order to identify settlement textures and landscape units in their natural evolution [11-13];

2. Analysis of the real situation in connection with forecasts of urban plans (identifying settlement areas and agricultural areas, proximity to the system infrastructure, service facilities);

3. Analysis of the productive matrix.

In the examined cases, illegal settlements are configured as urban districts, which clearly require to be integrated into the surrounding urban context. At the same time, they exist in areas characterized by the strong rural matrix. We catalogued these rural areas, using a schedule form, integrated with other information about the territory under study. This integration has been made possible by the realization of a dedicated Geographical Information System (G.I.S.) with the aim of adding different types of data. After collecting and confirming the data, a geodatabase for the elaboration of maps was drawn up through geographical analysis.

The construction of a G.I.S. has the dual aim of creating a tool for analysis of the state of the facts and providing valid support in the management of the phenomenon of illegal settlement. The G.I.S. has been constructed on the basis of geo-referenced map, while the geo-database consists of data related to the geographical location, the size, and the intended use of the buildings, detected by the catalogue form. This data can be used for the control of illegal settlements especially in respect of abuses relating to the intended use of the building. The overlay of different maps and different data in the G.I.S. has allowed the reading of the phenomenon of illegal settlements occurring in authorized buildings but with abuse of use: for example, a farm transformed abusively into a residential building (Fig. 2).

From the tables of analysis, a definite building index emerges, oscillating between 0.5 and $0.6 \mathrm{~m}^{3} / \mathrm{m}^{2}$, compared to the limit of $0.3 \mathrm{~m}^{3} / \mathrm{m}^{2}$ for agricultural areas. Further significant information that comes out of the spatial analysis is the housing volume index, which is equal to 237 cubic meters/inhabitant, more than double the minimum amount provided for by Ministerial Decree No. 1444 of 1968.

\section{RESULTS}

In Campobasso, due to the lack of planning tools to update the city according to its new needs, in 2006, the Municipal Administration began the process of drafting the Strategic Territorial Plan [14-17], involving 21 neighbouring municipalities, with the aim of building networks of cooperation and action agreements between the different actors involved [18].

With the same goals identified in the strategic plan, in 2007, the city council [19] identified the perimeters of urban areas with management problems. The elaboration of the program agreements could be implemented through a participatory process promoted by the municipality but extended to economic, social and cultural stakeholders [20] in order to solve problems of the Campobasso City Master Plan.

The aim of the resolution is to be an urban transformation plan, able to schedule and develop the many actions promoted by public and private operators. In particular, three integrated programmes (Programmi Integrati di Intervento) were analysed, involving different areas of the city, with the purpose of regeneration and recovery of urban texture. 


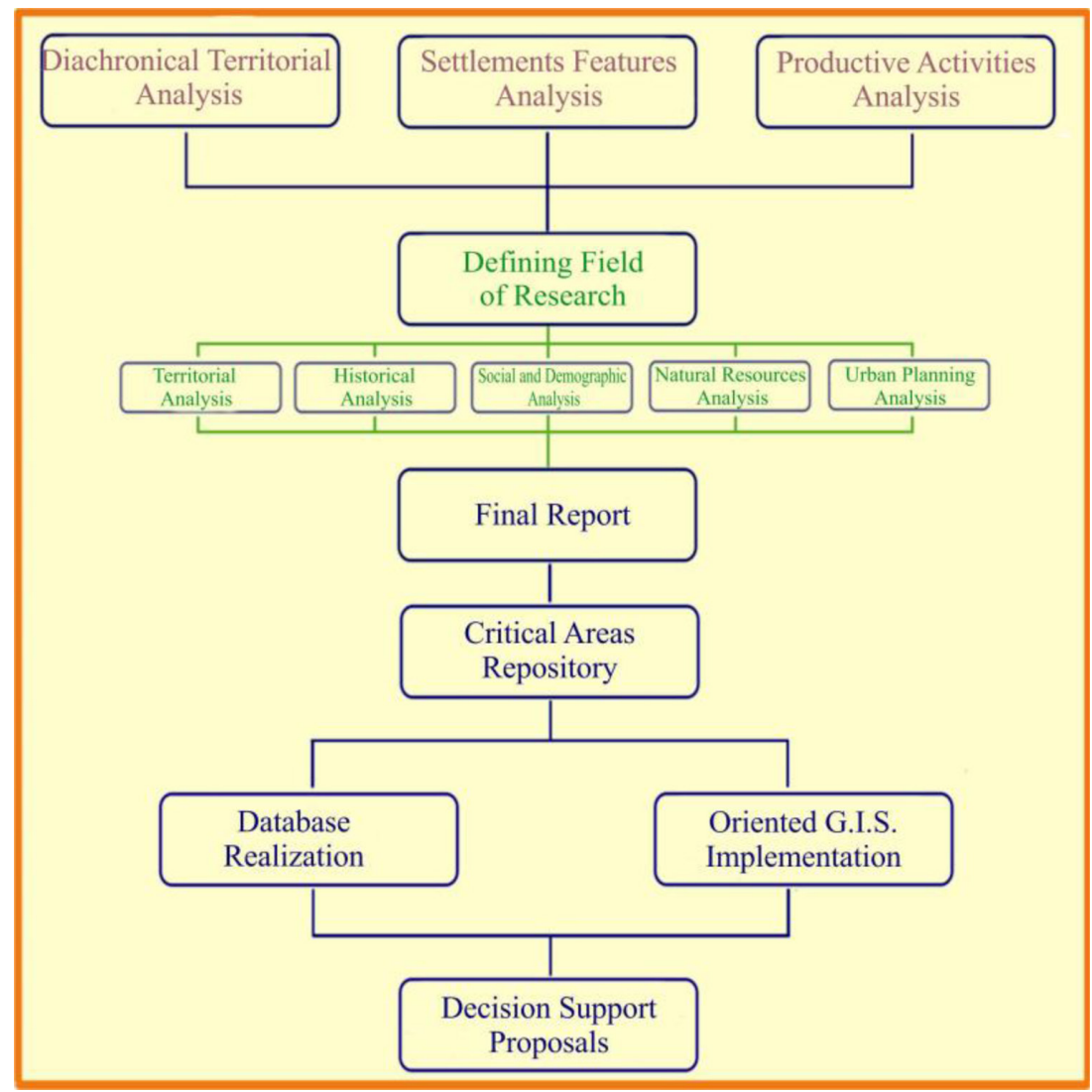

Figure 2: The Methodological Framework: the three phases (past condition, actual situation and productive aspects) merged to produce the Final Report in order to identify Critical Areas and the Decision Support Proposal (Source: 1.a.co.s.t.a. Laboratory 2013).

The first integrated programme, aimed at urban renewal, is the 'Quartiere CasaClima in San Pietro', a zone reclassified from a public green area to residential zone [21]. The programme, involving a total area of 36,000 square metres, aims to achieve urban regeneration in a strategic part of the city: between the railway station, the bus terminal, the directional zone and the university.

The project is set up as an urban system, in which all the structures that define the city (roads, housing, offices, commercial facilities and places for leisure) have been integrated into a system of green areas and connected to the existing city. There are 700 settled inhabitants: they are distributed across four buildings in a 5000 square meters urban park, with squares, gardens and tree-lined paths [22].

The second integrated programme, named 'Area a valle e a monte di Via Altobello e Via S. Giovanni in Golfo', and covering an area of about 40,000 square metres, already identified from the currently in-force Master Plan as an expansion area, completes the existing urban structure. It is characterized by areas designated for social housing, in proximity to the historic CEP district (Social Housing Coordination Committee established by the Presidential Decree of 01.25.1954) [23]. The capacity of the settlement is approximately 600 inhabitants, distributed across sub-sectors with different types of buildings (maximum five floors). 
The third integrated programme, named 'Tetti Bianchi', in via Facchinetti, falls into one of the perimeters of illegal settlements defined by the previously mentioned Commissioner Ad Acta Lucarino. This proposal provides for the co-existence of residential and commercial buildings in the same area. Between these two functional areas, a green park - which connects the new district with the neighbouring buildings - was sited. In this 27,000-square-metre area, a residential settlement (1,905 inhabitants) is provided, made up of four multi-family units in addition to four lots for the construction of mono and two-family units [24].

These areas are shown in Figure 3, together with other actions that the city has realized over the years in its building heritage: Detailed Plan of the Historical Center [25], Piazzetta

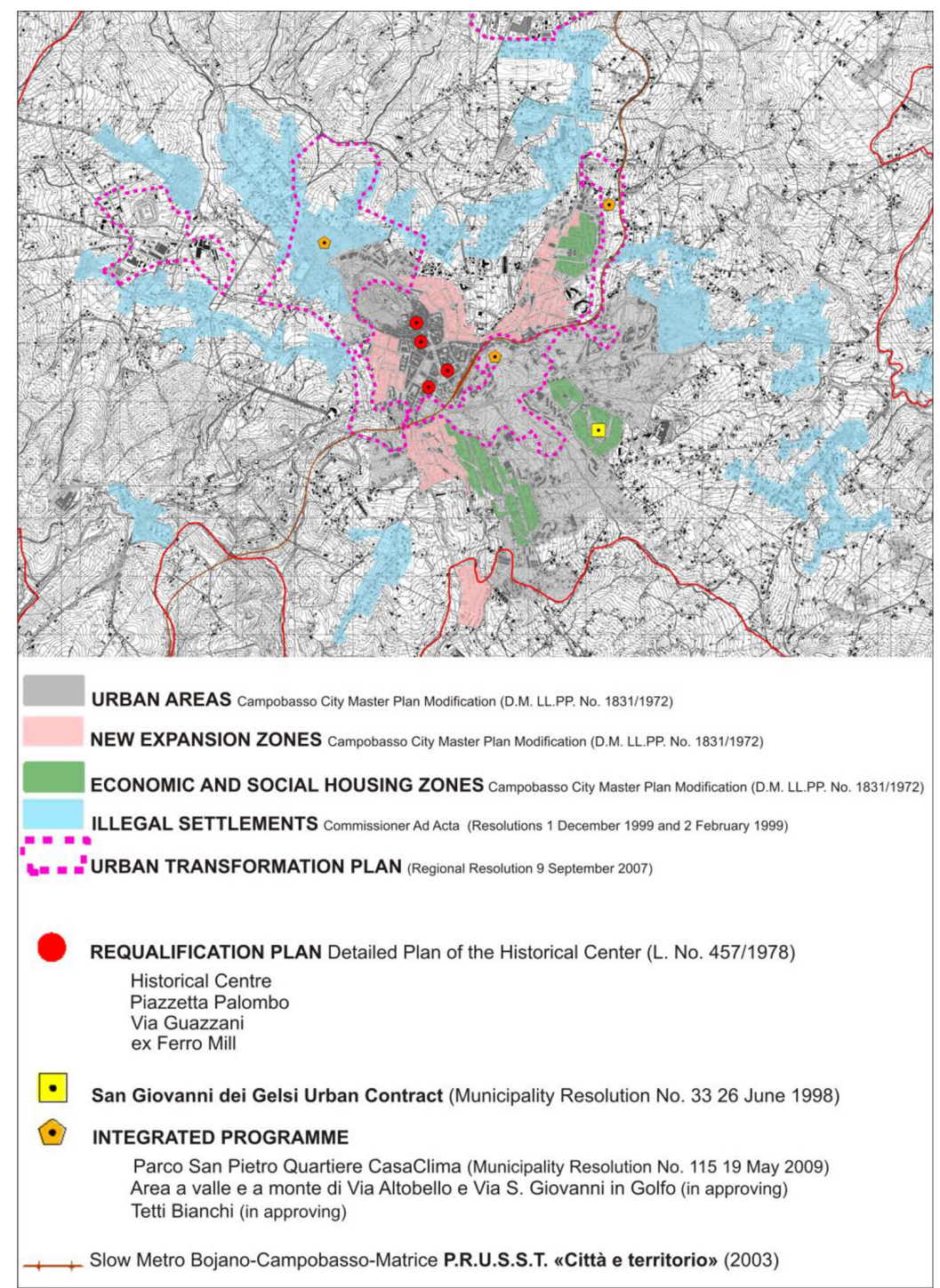

Figure 3: Recent transformation in the Campobasso area (Source: 1.a.co.s.t.a. Laboratory Processing 2015). 
Palombo Requalification Plan [26], via Herculanea Requalification Plan and Area 'ex Molino Ferro' Requalification Plan, named 'La città nella città' [27], Urban Contract (Contratto di Quartiere) San Giovanni dei Gelsi [28], the Urban Renewal Programme and the Local Sustainable Land Development - P.R.U.S.S.T. called: 'Città-Territorio' [29].

All these actions are located within the city centre but the proposed construction of an urban and extra-urban light rail system is of primary importance. This mobility system would use part of the existing Termoli-Campobasso and Campobasso-Rome railway lines. The project aims to increase the area served by the railway, with new stops, favouring a network connection system, using parking facilities, or by improving the frequency of train services in relation to people's needs [30-33].

\section{CONCLUDING REMARKS AND SUGGESTIONS}

The issue of the recognition of illegal areas is topical. In fact, only a few months ago, in accordance with the second version of the Regional Housing Plan [34], the municipality of Campobasso adopted Resolution No. 2/2016 to define the regulations for the urban requalification of illegal settlements. This new, recent proposal is designed to engage and encourage private initiative, by producing special plans aimed at the recovery of urban texture [35]. The analysis of land use evolution over the last 50 years showed significant increases in urban areas in the municipality of Campobasso: along the north-south route, the villages of Ferrazzano and Ripalimosani are involved. Moreover, the low land and population density confirm the rural nature of this area.

Nevertheless, an important question could be: 'Is it still useful to talk about urban renewal or is it better to convert areas to their agricultural vocation?'.

Certainly, there are some situations, such as our sample area, in which it is more convenient to return to the original agricultural vocation.

In this regard, it is very interesting to consider what the Veneto Region recently realized: they tried to reverse the trend, by introducing, in their Regional Law No. 4 of 16 March 2015, the so-called 'Green Modifications'. People interested in changing the use of their own property areas could propose to the municipality that these areas, actually useful for buildings, could be transformed into agricultural areas.

For this purpose, the municipality realized the urban reclassification, in accordance with the objectives of land consumption control and to reverse the process of land urbanization $[36,37]$. This initiative demonstrates that the municipality's behaviour is oriented to more careful planning policies to reorganize existing settlements. Moreover, they achieved a result in tax equity: in this way, citizens have to pay taxes for agricultural land. These taxes are much lower than those for land, which can be used for buildings.

From this perspective, the role of the new Landscape Plan is increasing. The Landscape Plan could underline the identity value, which includes the memories value and the economic value, which inevitably must take into account the actual land use. Moreover, the Landscape Plan could play a strategic role in connecting regional policy needs with local vocations, overstepping its traditional function of protecting the natural and environmental features of the land, in order to represent a reference for 'Landscape Management'.

\section{REFERENCES}

[1] Beguinot, C., Relation in attachment to D.C.C. No. 82 December 112000 "Variante Generale al Piano Regolatore Generale di Campobasso -Adozione, art.8 della L. 1150/42", 1998. 
[2] Vitiello, M., Per una legge urbanistica regionale in Piano Progetto Città 12/13 1992 Semestrale del Dipartimento di Architettura e Urbanistica dell'Università di Chieti. Facoltà di Architettura di Pescara, pp. 55-58, 1992.

[3] Cialdea, D., Il Molise. Una realtà in crescita. Aree protette ed attività agricole, Milano, Franco Angeli Editore, 1996.

[4] Cialdea, D., A new landscape planning approach in areas with a strongly rural matrix. in M. Campagna, A. De Montis, F. Isola, S. Lai, C. Pira, C. Zoppi (eds.) Planning support tools: policy analysis, implementation and evaluation, chapter 5, Franco Angeli, Milano, pp. 453-464, 2012.

[5] Cialdea, D. \& Fierro, F., "Forma vs tecnica: Il disegno della città vs Urbanistica dei piani nell'esempio di Campobasso" in (eds.) Società Italiana degli urbanisti, L'urbanistica italiana nel mondo. ATELIER 5, Roma/Milano, Planum publisher, pp. 655-663, 2014.

[6] Regione Molise Legge Regionale 14 Maggio 1985, n. 17, Disposizioni regionali di attuazione della legge $n .47$ del 28 febbraio 1985 recante norme in materia di controllo sull'attività urbanistica - edilizia, sanzioni, recupero e sanatoria delle opere abusive.

[7] Borgiotti, F., Mandolesi, E. \& Sciarretta, U., Piano regolatore generale di campobasso, approved by Decreto Ministero dei LL.PP., 27.08.1954.

[8] Piccinato, L. \& Antonelli, C., Piano Regolatore della Città di Campobasso, 1942.

[9] Amaturo, R., Decapoa, E. \& Tardella, G., Variante generale al Piano Regolatore Generale 1972. Adozione D.C.C. n.46 del 12/02/1970. Approvazione Decreto Ministero dei LL.PP. n. 1831 del 31/03/1972.

[10] Lucarino, G., Relazione tecnica e relazione previsione spese allegata alle Deliberazioni del Commissario ad acta del 12/01/1999 e del 22/02/1999 "per il recupero urbanistico, a mezzo di variante al Piano Regolatore Generale del Comune di Campobasso, dei nuclei abusivi di cui all'art. 2, comma 54, Legge 622/96, all'art. 29 Legge 47/85, alla Legge regionale 17/85", 1999.

[11] Cialdea, D. \& Maccarone, A., Territorial diachronic maps for the regional landscape plan. In M. Campagna, A. De Montis, F. Isola, S. Lai, C. Pira \& C. Zoppi (eds.) Planning support tools: policy analysis, implementation and evaluation, chapter 4, Franco Angeli, Milano, pp. 386-398, 2012.

[12] Cialdea, D. \& Mastronardi, L., Marginality phenomena and new uses on the agricultural land. Diachronic and spatial analyses of the Molise coastal area. TEMA Journal of Land Use, Mobility and Environment Special Issue June 2014, pp. 235-245, 2014.

[13] Cialdea, D. \& Mastronardi, L., L'interpretazione delle trasformazioni territoriali attraverso l'analisi delle funzioni delle antiche infrastrutture viarie: il caso dei Tratturi del Molise, in Atti della XXXV Conferenza scientifica annuale AISRe Associazione Italiana di Scienze Regionali dal titolo Uscire dalla crisi. Città, Comunità e Specializzazione Intelligenti, Padova, 2014.

[14] Comune di Campobasso, Piano strategico Territoriale di Campobasso e della rete urbana del Molise centrale. Documento preliminare di base per la discussione, Febbraio, 2007.

[15] Comune di Campobasso, Piano Strategico Territoriale di Campobasso e della Rete Urbana del Molise Centrale, Documento definitivo, 2008.

[16] Belli, A. \& Vitellio, I., Per una Campobasso solidale, sostenibile e sorprendente, Il Bene Comune, 35, 2007.

[17] Vitellio, I., Piano strategico territoriale di Campobasso, in Rapporto dal Territorio 2007, Inu Edizioni, 2008. 
[18] Quercio, N. \& Di Placido, A., Governo del territorio e mobilità urbana sostenibile: da ferrovia a metropolitana leggera. Urbanistica Informazioni, 263, pp. 13-17, 2015.

[19] Comune di Campobasso, D.C.C. n. 48 del 11/09/2007, Promozione di accordi di programma nel territorio comunale, 2007.

[20] Martino, D., Relation in attachment to D.C.C. n. 48 del 11/09/2007, Comune di Campobasso, Promozione di accordi di programma nel territorio comunale, 2007.

[21] Programma Integrato di Intervento (ex art. 16 L. 179 del 17/2/1992) in Variante alla Pianificazione Territoriale Urbanistica con attivazione di Procedura di Programma ai sensi dell'art. 34 del D. Lgs. 267 del 18/08/2000, Parco San Pietro Quartiere "Casa Clima”, Riclassificazione urbanistica decisa con Delibera di Giunta Consiliare n. 61 del 12/07/96 e con Delibera del Consiglio Regionale n. 219 del 15/06/99.

[22] De Pari, P., Rapporto preliminare. Verifica di assoggettabilità a V.A.S. del P.I.I. "Parco San Pietro" Quartiere Casa Clima, 2010.

[23] Di Leva, B. \& Giuliani, U., Rapporto preliminare. Verifica di assoggettabilità a V.A.S. del P.I.I. "Area a valle e a monte di Via Altobello e Via S. Giovanni in Golfo", 2012.

[24] Di Lallo, G. \& Di Lallo, R., Rapporto preliminare. Verifica di assoggettabilità a V.A.S. del P.I.I. “"Tetti bianchi”, 2012.

[25] Piano Particolareggiato del Centro Storico (Design Working Group: (arch. M. L. Benevento [Group Leader], arch. D. Boffa, arch. A. Di Donato, arch. D. Dolce, arch. S. Lalla, arch. A. Palladino, arch. G. Spina, ing. G. Canu, ing. R. Lemmo, ing. R. Mucci). 1978 (assignment) 1997 (first handing in) 2008 (last handing in).

[26] Piano di Recupero di Piazzetta Palombo (1982 (Competition) 1990 (Design) 2001 (End works).

[27] Piano di Recupero di iniziativa privata Aree "ex Molino Ferro" denominato "La città nella città (General Design arch. Nicola Guglielmi e Paolo Di Laura Frattura): 2000 (Design), 2006 (Starting Works), 2009 (End works).

[28] Piano di Recupero relativo al comprensorio di S. Giovanni dei Gelsi ai sensi della L. 457/78, art. 27 e 28, Contratto di Quartiere S. Giovanni dei Gelsi (approved by the Municipality Council Act No. 33 June 26 1998).

[29] P.R.U.S.S.T. Programma di Riqualificazione Urbana e di Sviluppo Sostenibile del Territorio Locale denominato: "Città Territorio" (Decreto del Presidente della Giunta Regionale 13 agosto 2001, n. 122).

[30] Cialdea, D. \& Maccarone, A., Il Piano Paesaggistico Regionale e la mobilità sostenibile. Planum, 27, pp. 23-31, 2013.

[31] Cialdea, D., The Landscape Features in the Urban Context. Sustainable Strategies for the small town in the South of Italy. In A. Gospodini (died.), Proceedings of the International Conference on Changing Cities II: Spatial, Design, Landscape \& Socio-economic dimensions, University of Thessaly Greece Editor, pp. 169-179, 2015.

[32] Cialdea, D., Un'infrastruttura "primaria" nelle Regioni dell'Italia centro-meridionale: Interventi per una Rigenerazione Territoriale. Urbanistica Informazioni, 263, pp. 1-2, 2015.

[33] Cialdea, D., La mappa della mobilità dolce e la pianificazione di itinerari di qualità. Urbanistica Informazioni, 263, pp. 17-20, 2015.

[34] Regione Molise, Legge Regionale 14 aprile 2015 n. 7, Disposizioni modificative della legge regionale 11 dicembre 2009, $n$. 30 (Intervento regionale straordinario volto a rilanciare il settore edilizio, a promuovere le tecniche di bioedilizia e l'utilizzo di fonti di energia alternative e rinnovabili, nonché a sostenere l'edilizia sociale da destinare alle categorie svantaggiate e l'edilizia scolastica). 
[35] De Camillis, G., Relation in attachment to D.C.C. No. 2 February 22016 "Comune di Campobasso Legge Regionale n. 7/2015 art. 3 TER e s.i.m Aggiornamento ed integrazione della Perimetrazione degli insediamenti abusivi”, 2016.

[36] Regione Veneto Legge Regionale 16 marzo 2015 n. 4 Modifiche di leggi regionali e disposizioni in materia di governo del territorio e di aree naturali protette regionali.

[37] Reho, M., Nord Est dopo il boom. Origami, pp. 7-8, 2016. 